\title{
Study on the Multinational Companies Global Strategy and International Economic Cooperation of Western Companies
}

\author{
Xiaoyan Zhou ${ }^{1}$ \\ ${ }^{1}$ Xi'an International University, Xi'an, Shaanxi, 710065 \\ 346591653@163.com
}

\begin{abstract}
KEYWORDS: Multinational Corporations; Western Enterprises; International Economic Cooperation
\end{abstract}

\begin{abstract}
Transnational corporations are an important product of global economic integration, to promote global economic integration and promoting regional development has an important significance in promoting. 20 species of the mid-1990s after the country's eastern and multinational enterprises formed close economic cooperation, but is less for the West China business investment and attention. According to the development of the western region development strategy to promote international economic cooperation with the western multinational companies, it is very important and meaningful. This paper discusses the necessity and possibility of Western multinational company international economic cooperation, in order to elaborate on the role in promoting the development of the western multinational enterprises of.
\end{abstract}

\section{Introduction}

With the bipolar world pattern is broken, the network era, global economic integration make the world economy shows a multipolar competition situation. No longer confined to national economies in the region, began cross-regional or cross-border economic cooperation, in order to achieve better resource allocation, cost savings, market expansion and other purposes. Today, multinational companies have become an important part of global economic integration, the economic development of all countries and regions play an important role in the promotion. Development of western China at the beginning of this background, is facing unprecedented challenges in front of all, but also ushered in a rare opportunity. Western Enterprises should give full play to the advantages of their areas, to achieve economic cooperation with multinational companies, to get a broader market, access to better economic efficiency.

\section{The role and importance of transnational corporations in the world economy and our national economy}

\section{A. TNCs Role and Importance in the World Economy}

Multinational companies are also known as multi-national companies refer to a company with business dealings in multiple countries or regions, and has factories or branches in different countries and regions to coordinate global management of the headquarters by setting. Multinational corporations can promote international trade and world economic growth. Data show that 90 of the world's multinational companies overseas sales to $\$ 5.5$ trillion, four times as much as total merchandise exports. With the continuous development and growth of multinational 
corporations, which will inevitably become the contemporary international economy and trade, the most important force.

Due to limitations in the form of multinational break area, the economic resources and global distribution of re-layout will accelerate the global economic development and give more reasonable layout.

\section{B. TNCs Role and Importance in Our National Economy}

Our country is a developing country in terms of capital investment and production technology has a big limitation. Multinational corporations, or our cooperation with multinational companies to increase capital investment and technical support China's economic development, accelerate the country's foreign trade commodity structure changes, so that some sectors of a qualitative leap, and promote the development of national economy . The multinational also provide a large number of new jobs, effectively alleviate the problem of employment.

\section{Development Trend of Transnational Corporations in the New Century}

Since the early 1990s, many multinational companies began to operate globally. In 2004, the world's largest 100 TNCs overseas assets reached 53.4\%, transnational index reached 56.8\%. More and more multinational companies are not only in developing countries, as the main objectives of cooperation and expansion of the market, but the onset of the global development strategy. M \& A strategic approach is its most obvious manifestations.

M \& A is not just a simple acquisition, more powerful combination of expression. As international head side to speed up the process of trade liberalization and TNCs in pursuit of a better economic efficiency and more advanced technology, have to share resources, to avoid vicious competition or regional conservation brought internecine, such as Microsoft's acquisition of Nokia event. Apple mobile phone as the representative of the rise of smart phones, mobile phones have had to make the dominance of Nokia phones gradually be forced out of the market situation. Microsoft and Nokia, namely Nokia and ultimately to avoid bankruptcy and led to the loss of market resources, while Nokia has re-use of market resources and technical support.

Multinational companies have established a global economic organization, market competition is also a global scale. UNCTAD reported that the past 20 years, the amount of mergers and acquisitions of transnational corporations to $41 \%$ annual growth rate, in 2000 the total global multinational M \& A has more than one trillion US dollars, reaching \$ 1.143 trillion. With the continuous development of multinational companies, corporate mergers and acquisitions in developing countries and developed countries will be more and more. M \& A multinational saving more development funds to develop a broader overseas market, provide better management concept, technical support and funding to effectively realize the complementary advantages between enterprises.

The development strategy and mode of operation multinational globalization is for money. The flow of technology and management, led the industrial structure adjustment is relatively backward countries and regions, so as to promote sustained world economic growth. But multinational companies in terms of profits for the purpose, the pursuit of profit maximization, whether acquisitions or a change in strategy, both in order to obtain greater benefits. Therefore developed and developing countries TNCs to define their goals, mutual promotion and mutual cooperation, to avoid inappropriate response caused huge impact on their economies. 


\section{The Necessity and Possibility of Multinational Companies and Western Economic Cooperation}

Since the beginning of the western development strategy, the western market and resources are on a certain degree of development. However, due to management of the western companies are still more traditional, there is no thorough conversion. So whether it is technical support or management level, we are in a relatively backward stage. Under such a background and then, if there is no external support and promote western business is difficult to rely on their own strength to get rid of existing difficulties.

And after China's accession to WTO and APEC, to greatly reduce tariffs and eliminate trade barriers and opening up China's market to enhance the freedom of trade. Especially after the East Asian financial crisis, East Asian countries have all accelerated the pace of investment and trade liberalization. Join the two international organizations to fulfill the obligations and requirements after, Chinese enterprises to increase cooperation with multinational companies to promote trade liberalization and optimization of our allocation of resources.

Since the 1990s, multinational corporations began with the formation of the country's eastern business scale, systematic economic cooperation, greatly promote the economic development of eastern China. But with the development of the market saturation of resources in eastern and eastern optimization, funding and technical support no more room for development, has not yet been fully developed west has a huge market potential.

Economic reasons, the western region is lagging behind mainly for the investment is not enough, low level of technology and more labor-intensive and primary processing enterprises. The multinationals can provide adequate levels of capital investment and technical opportunities, it is a lot of labor resources and market needs. If multinational corporations and Western companies reached economic cooperation, it is very much in line with the fundamental interests of both the development needs. Although lagging behind economic development in western China, but western companies already have the basic conditions for cooperation with transnational corporations. Since the reform and opening up, China's western support and development, making some western companies have sufficient market competitiveness, has a sound management programs and technical personnel, and tourism, power, chemical and other industries in the western region have been to a certain extent development, complete with multinational economic cooperation reached basic skills.

\section{Strategic Thinking of Western Companies and Multinational Economic Cooperation}

Western Development is not a short-term development plan, but a strategic approach and long-term development objectives. During the process of developing the western region, the western enterprises should pay attention and correct understanding of the opportunities and challenges of the current global economic integration to bring their own, gradual transformation of the western economic environment, making it more likely to have the condition and investment.

Unlike multinational companies have completed the internal adjustment and reform, China's enterprises are still at the stage of the western internal adjustment and reform. In the absence of complete "old mission", the new challenges and competition will be followed, inevitably cause some companies to Western pressure. Western Enterprises must unswervingly follow the state guidelines and policies, steadily to complete self-transformation, the establishment of good internal management structure and generate ways to enhance their market competitiveness, establish a sound system of enterprise development, improve the employment system. Through the 
establishment of a sound system, and gradually complete the reform of the internal mechanism, making it more capability with international standards.

Western Enterprises to understand, before reaching economic cooperation with multinational companies must first have a certain understanding of its economic integration with the current global environment, so as to provide an efficient, quality of internal self-adjustment and reform. After reaching economic partnerships with multinational companies, it is the first multinational learning experience of ideas, ways and techniques, active learning which can develop into transnational corporations' success. Cooperative learning, to enhance their cooperation to market competitiveness, and promote western economic development, economic cooperation is reached with multinational fundamental purpose.

Strategic approach is in understanding the target market and multinational companies, the western enterprises according to their own situation to select the appropriate targeted multinational companies. Western Enterprises with a certain strength to choose their own business goals and cooperating with each other to find the consistent multinationals, which can effectively improve the success rate and effectiveness of cooperation. After reaching cooperation, western multinational companies can provide funds for the construction of the West into the construction area of basic industries in the entire western enterprises and multinational companies to establish a good foundation. Appropriate to expand the areas of economic development, not confined to a single project. On the western multinational companies can provide resources for the development of deep processing projects with strong market potential and has high profits, such as characteristics of agricultural production, wine manufacturing. These are based on reasonable choices and have strength of multinational companies as a prerequisite, only the multinational companies with strong economic strength to achieve cooperation, to its advanced technology to enhance their market competitiveness of enterprises become favorable power in order to achieve economic cooperation. " win-win "objective.

\section{Conclusion}

TNCs accelerate the development of international trade, accelerate the re-layout optimization and market the world's resources for developing countries to bring adequate development funds and advanced infrastructure support. Western Enterprises to correctly recognize the opportunities and challenges of global economic integration, the Western emphasis on the construction of good basic industry, targeted to select the strength of the transnational corporations, in order to maximize the use of each other's resources to enhance their economic growth, with its own market competitiveness of enterprises, in order to achieve economic cooperation with multinational companies to reach the true meaning.

\section{REFERENCE:}

[1] Zhao Jinping, Hu Jiangyun, zhao Fujun. "China's development impact on the world economy" group, China Development on World Economy [J]. Management World, 2014,10: 1-16.

[2] Liu Yunfen Zhou Yingchao, Fan Libo. Evolution of Strategic Management Theory and Practice of Global Vision China Enterprises - "2014 China's strategic management scholars Forum" [J]. Economic Management, 2014,12: 186-193.

[3] Wang Yue. global companies - multinationals new stage of development [J]. globalization, 2015,11: 44-65 + 134. 
[4] Li Nan, Luo Huo. Chinese enterprises to accelerate the process of internationalization of Strategic Thinking [J]. academia, 2013,05: 81-89 + 283.

[5] Gu Xiujun. The study cross-cultural marketing strategy [J]. Guxiu Jun multinational companies in China Chinese market, 2011,18: 46-48 + 55 .

[6] Liu rehabilitation multinational business philosophy and Its Implications for Private Enterprises in China [J]. Party School Sinica, 2013,05: 47-50.

[7] Yu Kexin. China's western-oriented business strategies and countermeasures vector ASEAN international operations - with a resource-based enterprises and the processing industry as an example [J]. Economic Issues, 2012,01: 43-47 + 112 .

[8] Yang Dakai, Yang Jie. Trend multinational and local companies innovative cooperation and policy recommendations [J]. Fiscal Studies, 2015,10: 100-106. 